In spite of this scientific and commercial success, the people who carry the burden in research do not see themselves in a secure profession. Both output of and demand for chemists has declined during this decade and there is evidence that the quality of the newly qualified has dropped. The medical and legal professions, on the other hand, control both entry and the right to practice as well as the discipline of their professions, thus evading the cyclical imbalance in supply and demand so often felt by scientists.

Science as a profession is in a weak position. The best scientists are evenly spread over the country and not concentrated in the capital with day to day access to Whitehall.
Salary structures are strongly influenced by central government because the latter is the major employer, basing its rewards on comparability with industry which in turn compares with civil service salaries. It is a small but vicious circle which depresses salaries.

If the recent Bullock proposals for worker-directors in Britain are implemented along anything like the lines suggested in the majority report, the new directors are unlikely to include research scientists. Yet scientists are a major wealth-creating source. They may not continue to provide for the community if their views are not sought or are disregarded, and certainly if they are driven overseas by the tax structure.

\title{
A parable on recombination
}

DeWitt Stetten offers some personal thoughts on the management of hazards in recombinant DNA research

ScIENTISTS and nonscientists are currently polarised in their assessments of the hazards attached to the creation and handling of recombinant DNA molecules. Whereas the hazards are of unknown dimensions, the anxieties are clearly great: but the magnitude of the anxiety is a very imperfect measure of the magnitude of the hazard. Among the diverse views we are seeking an area of possible agreement or, better yet, an area of truth.

Truth is sometimes found in unexpected places. It may be recalled that Jonathan Swift, famed satirist and author of Gulliver's Travels, while serving as Dean of St Patrick's in Dublin, considered the disastrous problem of the famine among the Irish peasants which was aggravated by the high birth rate and the abundance of children. He analysed the problem in 1729 in an essay entitled 'Modest Proposal for Preventing the Children of Poor People from being a Burden to their Parents or the Country,' in which, with all pretense of reasonableness, he concluded that the entire problem could be solved if the people of Ireland ate the children. In view of the evident success of Swift's satire, I am taking the liberty of presenting here a parable which I call 'Genetic Recombination-A Modest Proposal'.

After all, recombinant DNA technology is a special case of a far more general phenomenon-that of genetic recombination itself, where genetic material from two sources is repeatedly combined within a single cell. It happens when an oncogenic virus invades a mammalian cell, or when a bacteriophage invades a bacterium. It happens when two bacteria enter into conjugation and transfer plasmid DNA from one to another. In the laboratory it can be achieved through the hybridisation of eukaryote cells from widely differing species, and it is of course the very basis of sexual reproduction.

A form of this kind of experimentation which has been popular for a very long time indeed results in the fertilisation of the human ovum. I refer to this exercise as an experiment, because it always is experimental in that the outcome is not known a priori. At this time we can not even foretell the sex of the offspring, much less any of the details of its anatomy or character. Yet the experiment, whereas it provides great possibilities of useful and benevolent results, does have a real hazard. Textbooks of obstetrics contain many engrossing photographs of anatomical monsters which have resulted from this process, but it seems to me that the very worst monsters, the behavioural ones, are not included. These may be divided into two classes-the societal monsters such as gangsters, typified by Al Capone, and the international monsters, exemplified by Adolf Hitler.

Clearly, some of these monsters possess a survival advantage over the rest of us. One has merely to note the direction in which the machine gun which the gangster carries is pointed to ascertain which party is in the better position to survive the encounter. Of particular interest is the experiment conducted nearly ninety years ago by the parents of Adolf Hitler. The maternal ovum may be construed in this case as the host, while the paternal sperm clearly was the vector, bearing as it did a charge of DNA which was foreign to the host. The conceptus which resulted was carefully cloned under reasonably sterile and controlled conditions, and there arose an individual who became, directly or indirectly, responsible for the premature deaths of $4 \times 10^{7}$ human beings in the course of about eight years. This mortality is certainly large, even in the parlance of the epidemiologist.

When scientists first began to appreciate the danger attached to the fertilisation of human ova, they directed attention to the matter and called for an immediate moratorium. Since the hazard seemed to be of enormous proportions, the federal government soon became involved; and by and by, a Presidential commission was established to consider the problem and to determine its best resolution. With the moratorium still in effect, one alternative solution proposed was to sterilise all adults, male and female. It was forecast that this procedure would probably work, but it would be quite costly. For this reason, the General Accounting Office, which has the responsibility of surveying costly federal projects, gave its attention to the matter and pointed out that sterilising of either the male or the female population would probably achieve the same desired effect at half the cost. To decide whether to sterilise all males or all females, a special panel of the Equal Employment Opportunity Commission was convened which, with Solomonic wisdom, recommended that since there were approximately equal numbers of males and females in the population at risk, it would appear appropriate to sterilise half of the males and half of the females.

A small experiment was conducted on normal volunteers to test the effectiveness of this procedure, and it was found, for reasons which are still unclear, that this procedure would not yield the desired result. After considerable deliberation, the commission recommended that experiments in human impregnation might proceed with caution in certain designated centres, provided steps were taken to preclude pollution of the environment. It was determined that experiments could be conducted under P4 physical containment with all the manipulations to be carried out in class III safety cabinets which, in the usual fashion, would have their entry and exit ports protected either by autoclaves or by incinerators. Only in this way could the public be assured that no monsters would escape to pollute the environment and damage the ecology. The econiche which we so comfortably occupy would not be threatened by another generation which predictably would perform less nobly than we had done. 